\title{
Texture, colour and sensory properties of non-fat yoghurt as influenced by tara gum or combinations of tara gum with buttermilk powder
}

\author{
Dilek Say ${ }^{1 *}$, Mostafa Soltani ${ }^{2,3}$, Nuray Güzeler $^{4}$
}

\author{
'Cukurova University, Vocational School of Pozanti, 01470 Pozanti, Adana, Turkey \\ IIslamic Azad University, Tehran Medical Sciences, Faculty of Pharmacy, \\ Department of Food Sciences and Technology, Tehran, Iran \\ ${ }^{3}$ Islamic Azad University, Tehran Medical Sciences, Nutrition and Food Sciences Research Center, Tehran, Iran \\ ${ }^{4}$ Cukurova University, Faculty of Agriculture, Department of Food Engineering, Adana, Turkey \\ *Corresponding author: dsay@cu.edu.tr
}

\section{Abstract}

The texture, colour and sensory properties of non-fat yoghurts prepared with different tara gum concentrations $\left(0.25,0.50\right.$ and $\left.1.0 \mathrm{gL}^{-1}\right)$ and different tara gum (TG) with buttermilk powder (BP) combinations $\left(0.25+10,0.50+10\right.$ and $\left.1.0+10 \mathrm{gL}^{-1}\right)$ were investigated during storage. While addition of 0.25 and $0.50 \mathrm{gL}^{-1}$ of tara gum caused an increase in firmness, consistency, cohesiveness, viscosity index of yoghurt samples, use of $1 \mathrm{gL}^{-1}$ of tara gum and combinations of tara gum with buttermilk powder led to a decrease in these properties. During the storage period, increasing the concentration of tara gum resulted in significant decrease in $L^{*}$ and $a^{*}$ values, significant increase in $b^{*}$ value in yoghurt. Sensory properties of non-fat yoghurts supplemented with 0.25 and $0.50 \mathrm{gL}^{-1}$ did not significantly differ from those of control yoghurts. In contrast, use of $1 \mathrm{gL}^{-1}$ of tara gum and combinations of tara gum and buttermilk powder caused a significant decrease of sensory properties of non-fat yoghurt.

Key words: buttermilk powder, non-fat yoghurt, sensory properties, tara gum, texture properties 


\section{Introduction}

The yoghurt manufacturing generally contains heating milk at high temperatures $\left(80-85^{\circ} \mathrm{C}, 20\right.$ 30 min or $\left.90-95{ }^{\circ} \mathrm{C}, 5-10 \mathrm{~min}\right)$, denaturation of whey proteins, interaction between $\mathrm{k}$-casein and denatured whey proteins on the surface of casein micelles, decreasing the $\mathrm{pH}$ from typical $\mathrm{pH}$ of milk (6.6-6.7) to isoelectric point of caseins (4.6) and eventually, creation of yoghurt gel network formed from caseins and whey proteins which trapped milk fat and water (Everett and McLeod, 2005; Aziznia et al., 2009). Milk fat has an important role in formation of quality properties in yoghurt. In this context, manufacture of yoghurt with low/non-fat milk may cause undesirable flavour and poor texture. However, it has been reported that consumption of milk fat may increase cholesterol and the risk of cardiovascular disease (Romeih et al., 2014; Zha o et al., 2018). Thus, in order to fulfil the demands for consumption of low/non- fat milk products, several studies have been carried out for replacement of milk fat with suitable materials i.e. locust bean gum (Ünal et al., 2003), barley beta-glucan (Brennan and Tudorica, 2008), whey protein concentrate (Sandoval-Castilla et al., 2004; Aziznia et al., 2008) and inulin (Guven et al., 2005; Crispin Isidro et al., 2015; Balthazar et al., 2015).

Tara gum (TG) that is obtained from the seed endosperm of Caesalpinia spinosa tree has galactomannan polysaccharides with a linear main chain of (1-4)-B-D-mannopyranose units linked with (1-6)-a-D-galactopyranose branched units. In addition to using TG as stabilizer or thickener agent in food industry, it can be used in the production of edible films and synthesis of superabsorbent hydrogels due to unique hydrocolloid nature and low cost compare with similar gums such as guar gum and locust bean gum (Antoniou et al., 2014; Wu et al., 2015; Ma et al., 2016).

Buttermilk is natural and valuable by product of butter manufacturing process and used in formulation of different food products. The agitation power used during butter-making causes disruption of milk fat globule membranes (MFGM) and releases it into aqueous phase. The presence of MFGM with confirmed anti-pathogenic properties along with caseins, whey proteins and lactose may add a special nutritional and health promoting values to buttermilk. It was reported that the use of buttermilk in maximum amount of $2 \%$ can result in achieving desirable physical and sensory properties in yoghurt (Dewettinck et al., 2008; Romeih et al., 2014; Ali, 2019; Yıldız and Bakırcı, 2019).

The effect of using TG instead of milk fat on the physical and sensory properties of yoghurt has not been studied yet. Therefore, the aim of this study was to investigate the influence of using various concentrations of TG, alone or mixed with buttermilk powder (BP) at certain proportions on the texture, colour and sensory characteristics of non-fat yoghurt along 15 days of cold storage period.

\section{Materials and methods}

\section{Materials}

Raw cow milk used in the experiments was provided from Animal Husbandry branch of Faculty of Agricultural, Cukurova University, Adana, Turkey. Skimmed milk powder was purchased from Pinar Süt A.S. (Istanbul, Turkey). Buttermilk powder (BP) (protein: $33.6 \%$, fat: $5.7 \%$, lactose: $50.3 \%$, moisture: $3.9 \%$ ) and tara gum (TG) (protein: $0.7 \%$, ash: $0.9 \%$, moisture: $12.83 \%$ ) were obtained from Enka Süt San. A.S. (Konya, Turkey) and Boensen Gıda San. Tic. (Istanbul, Turkey), respectively. Lyophilized yoghurt starter culture of YC350 (Streptococcus thermophilus and Lactobacillus delbruckii subsp. bulgaricus) was procured from CHR-Hansen Company (Hørsholm, Denmark).

\section{Yoghurt manufacturing}

Raw milk was skimmed using a cream separator (Elecrem, Vanves, France) preheated to $48-50^{\circ} \mathrm{C}$ and the fat content was adjusted to $3 \%(\mathrm{v} / \mathrm{v})$ and $<0.1 \%(v / v)$ for manufacture of full-fat (CFY) and non-fat yoghurt (CNY), respectively. Then, skim milk powder was added at $2 \%(\mathrm{w} / \mathrm{v})$ to both, full fat and skim milk. Standardized milk was divided into seven parts, the first part served as control, while TG and BP were added into non-fat milk at the different levels as followed: $0.25 \mathrm{gL}^{-1}$ of TG (TY1), 0.50 $\mathrm{gL}^{-1}$ of TG (TY2), $1.0 \mathrm{gL}^{-1}$ of TG (TY3), $0.25 \mathrm{gL}^{-1}$ of $\mathrm{TG}+10 \mathrm{gL}^{-1}$ of BP (TBY1), $0.50 \mathrm{gL}^{-1}$ of $\mathrm{TG}+10 \mathrm{gL}^{-1}$ of $\mathrm{BP}$ (TBY2), $1.0 \mathrm{gL}^{-1}$ of $\mathrm{TG}+10 \mathrm{gL}^{-1}$ of $\mathrm{BP}$ (TBY3). 


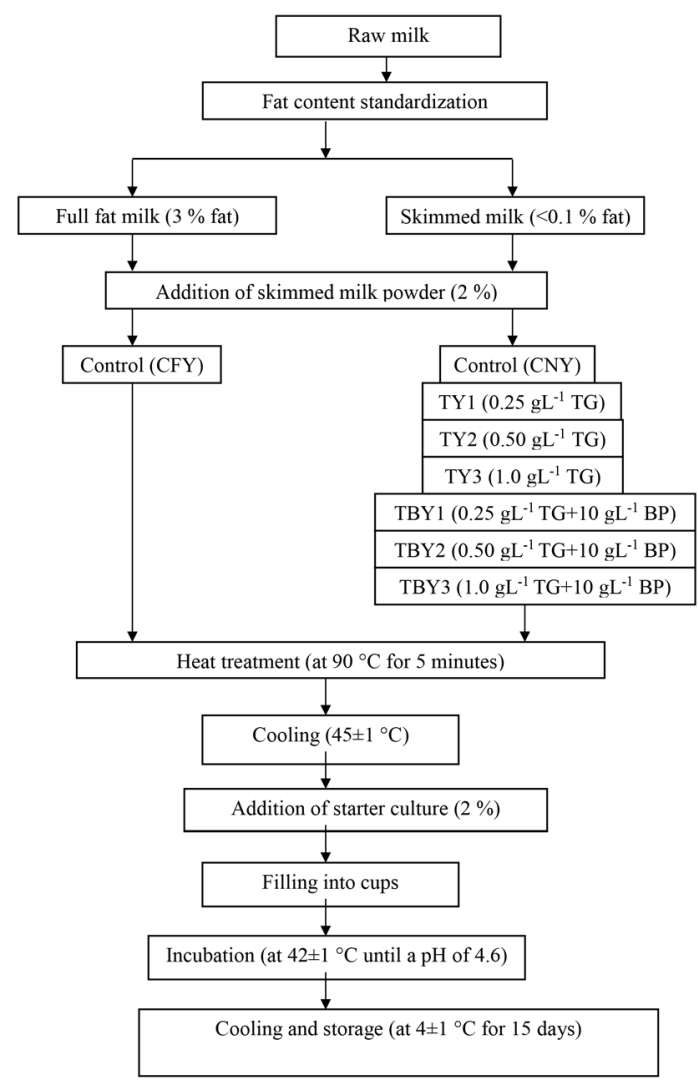

FIGURE 1. Process flow chart for yoghurt production with tara gum and buttermilk powder

After blending the milk with skimmed milk powder, TC and BP, the mixture was homogenized with a mixer (HA 3020, Tokyo, Japan) until all ingredients dissolved. Heat treatment $\left(90^{\circ} \mathrm{C}\right.$ for 5 min), cooling (to $45^{\circ} \mathrm{C} \pm 1{ }^{\circ} \mathrm{C}$ ) and adding starter culture ( $\left.2 \% \mathrm{v} / \mathrm{v}\right)$ were applied to all batches, respectively. Then, the milk of all treatments was filled into $200 \mathrm{~mL}$ plastic yoghurt cups before incubation at $42 \pm 1^{\circ} \mathrm{C}$. At the end of incubation ( $\mathrm{pH} 4.6)$, all yoghurt samples were stored at refrigerator temperature $\left(4 \pm 1^{\circ} \mathrm{C}\right)$ for 15 days. Yoghurt production was carried out in triplicate. The resultant yoghurts were analysed after 1 , 8 and 15 days of storage. Figure 1 illustrates the yoghurt production process. Forming of yoghurt gel was not observed for TBY3 sample so it was excluded from the experimental design and analyses were performed with seven samples.

\section{Texture analysis}

Texture characteristics were analysed using TAXT Plus Texture Analyser (Stable Micro Systems,
Godalming, UK) equipped with a $500 \mathrm{~N}$ compression load cell and operating at $1 \mathrm{~mm} \mathrm{~s}^{-1}$ head speed. The probe was a $25-\mathrm{mm}$ acrylic cylinder moved speed of $5 \mathrm{~mm} \mathrm{~s}^{-1}$ and test speed of $1 \mathrm{~mm} \mathrm{~s}^{-1}$ through 10 $\mathrm{mm}$ within the sample (Dinkci, 2012). The firmness, consistency, cohesiveness and viscosity index were determined during storage period and the results were presented as the mean of three replicates of each experiment.

\section{Colour evaluation}

The colour parameters, $L^{*}$ (brightness, 0 = black, $100=$ white), $a^{*}\left(+:\right.$ red, - : green) and $b^{*}(+:$ yellow, - : blue) of yoghurt samples were measured during the storage period using a Minolta Chroma Meter CR-400 (Minolta Camera Co. Ltd, Osaka, Japan). The chrome $\left(C^{*}\right)$, white index $(\mathrm{WI})$, and yellowing index (YI) were calculated using the following equation (Güler and Park, 2011; Marand et al., 2020):

$$
\begin{gathered}
C^{*}=\left(\left(a^{*}\right)^{2}+\left(b^{*}\right)^{2}\right)^{0.5} \\
W I=100-\left(\left(100-L^{*}\right)^{2}+\left(a^{*}\right)^{2}+\left(b^{*}\right)^{2}\right)^{0.5} \\
Y I=142.86 b^{*} \cdot L^{-1}
\end{gathered}
$$

\section{Sensory analysis}

Nine expert panelists whose average age was 23 and familiar with yoghurt from the Laboratory of Milk and Dairy Products at Cukurova University participated in sensory evaluation of the yoghurt samples. Evaluation process were performed after 1, 8 and 15 days of storage using a form prepared according to five-point hedonic scale (1: unacceptable; 2: somewhat acceptable; 3: acceptable; 4: desirable; 5: excellent). Three digit coded samples were removed from the refrigerator $\left(4 \pm 1^{\circ} \mathrm{C}\right)$ and presented to each panelist randomly (Brennan and Tudorica, 2008). In order to cleanse panelists' palates between samples, water and bread were provided for them. In terms of sensory properties, the appearance, consistency (as perceived by spoon or in the mouth) and odor and taste of samples were assessed using a form according to the Turkish Standards for yoghurt (Anon., 1989). Moreover, the sum of sensory scores given to yoghurt samples by panelists during storage was presented as total sensory score. 


\section{Statistical analysis}

Analysis of variance (ANOVA) of SPSS program (SPSS package program, version 22.0, SPSS Inc., USA) was used for determination of the differences among the yoghurt samples during 15 days of storage. Duncan's multiple range tests was also used for determination of different groups. The significance level for obtained results was considered at $a=0.05$ or $a=0.01$ (Guo et al., 2018).

\section{Results and discussion}

The chemical compositions of full-fat milk and non-fat milk used for yoghurt manufacturing were determined as $12.14 \pm 0.07 \%$ and $9.42 \pm 0.06 \%$ for total solid, $3.10 \pm 0.02 \%$ and $0.10 \pm 0.00 \%$ for fat and $3.19 \pm 0.03 \%$ and $3.33 \pm 0.02 \%$ for protein, respectively. The dry matter, fat and protein contents were found as $13.22 \pm 0.04 \%, 2.93 \pm 0.06 \%$ and $4.18 \pm 0.16 \%$ for $C F Y, 10.79 \pm 0.37 \%, 0.10 \pm 0.00 \%$ and $4.88 \pm 0.17 \%$ for NFY, $10.76 \pm 0.26 \%, 0.10 \pm 0.00$ $\%$ and $4.68 \pm 0.18 \%$ for TY1, $10.65 \pm 0.36 \%$, $0.10 \pm 0.00 \%$ and $4.54 \pm 0.21 \%$ for TY2, $10.90 \pm 0.35$ $\%, \quad 0.10 \pm 0.00 \%$ and $4.48 \pm 0.26 \%$ for TY3, $11.82 \pm 0.11 \%, 0.10 \pm 0.00 \%$ and $4.95 \pm 0.12 \%$ for TBY1, $11.86 \pm 0.17 \%, 0.10 \pm 0.00 \%$ and $5.18 \pm 0.06$ $\%$ for TBY2.

\section{Texture profiles of yoghurts}

Reduction of $\mathrm{pH}$ in the result of activity of starter cultures is caused to aggregation of casein micelles and formation of disulphide bonding between $\mathrm{k}$-casein and denatured whey proteins and led to create a three dimensional gel network in yoghurt which trapped fat and serum phase (Sah et al., 2016). In this context, change in chemical composition may cause a change in structure and texture of yoghurt. Texture profiles of yoghurt samples during the storage period were presented in Table 1. Firmness is the force required to attain a certain deformation and one of the important properties analysed for evaluation of texture quality in yoghurt. In terms of firmness, no significant decrease $(p>0.05)$ was determined at maximum force in compression for CNY compared with CFY. Reduction of fat content has been reported by several researchers as the reason for decrease of firmness in semi-fat and non-fat yoghurts in comparison with full-fat ones (Sandoval-Castilla et al., 2004; Pereira et al., 2006; Aziznia et al., 2008). On the other hand, while addition of 0.25 and $0.50 \mathrm{gL}^{-1}$ of tara gum led to a significant increase in firmness of yoghurts compared with control full-fat and non-fat yoghurts $(p<0.05)$, the firmness value decreased in a non-fat yoghurt manufactured with incorporation of $1 \mathrm{gL}^{-1}$ of TG. Interactions between low concentrations of polysaccharide gums and caseins, especially k-casein which is located at the surface of casein micelles, may contribute to formation of a structure with higher capacity of trapping water. Owing to it's anionic nature TG can absorb onto the casein micelles during acidification which may lead to formation of strengthened casein network in yoghurt by connecting the micelles through the narrow strings of gum. However, when the concentration of TG increased to $1 \mathrm{gL}^{-1}$, due to depletion flocculation, a more compact micellar aggregate structure is formed which resulted in a product with reduced firmness value and liquid like structure (Everett and McLeod, 2005; Aziznia et al., 2009; Wu et al., 2015). Also, Guven et al. (2005) and Ladjevardi et al. (2015) reported that using high concentrations of inulin and husk gum as fat replacer in manufacture of low-fat yoghurt caused trapping of casein aggregates in viscose polysaccharide phase and fewer interactions among caseins and formation of weaker protein gel. On the other hand, the firmness value increased in all yoghurt treatments during storage. It was reported that increasing the acidity during storage may lead to an increase in water holding capacity and, consequently, an increase in gel firmness of yoghurt (Oraç and Akın, 2019). Similar results have been reported by Karaca et al. (2019) for low-fat and non-far probiotic set-type yoghurt fortified with fibre-rich persimmon and apple powders and by Oraç and Akın (2019) for set-type yoghurt stored in different temperatures.

Consistency is defined as the area under the force versus time curve obtained during penetration of the probe into the sample. Among yoghurt manufactured using different concentrations of TG, the highest consistency was determined in yoghurt manufactured with $0.5 \mathrm{gL}^{-1}$ of TG during storage. It was illustrated that appropriate concentrations of gum, may cause a good polysaccharide/protein 
TABLE 1. Texture profiles of yoghurts manufactured with different concentrations of TG or BP and their combinations ( $n=3$ )

\begin{tabular}{|c|c|c|c|c|}
\hline & Yoghurts & Day 1 & Day 8 & Day 15 \\
\hline \multirow{7}{*}{ 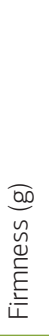 } & CFY & $236.71 \pm 24.24 \mathrm{AB}^{\mathrm{a}}$ & $240.13 \pm 18.81 \mathrm{AB}^{\mathrm{a}}$ & $251.01 \pm 14.69 \mathrm{AB}^{\mathrm{a}}$ \\
\hline & CNY & $217.73 \pm 15.11 \mathrm{~B}^{\mathrm{a}}$ & $225.30 \pm 13.53 \mathrm{~B}^{\mathrm{a}}$ & $232.70 \pm 15.98 \mathrm{~B}^{\mathrm{a}}$ \\
\hline & TY1 & $239.66 \pm 20.95 A^{a}$ & $248.80 \pm 11.49 \mathrm{AB}^{\mathrm{a}}$ & $273.64 \pm 25.71 \mathrm{AB}^{\mathrm{a}}$ \\
\hline & TY2 & $270.63 \pm 12.54 \mathrm{~A}^{\mathrm{a}}$ & $278.69 \pm 20.07 A^{a}$ & $302.63 \pm 11.48 \mathrm{~A}^{\mathrm{a}}$ \\
\hline & TY3 & $135.05 \pm 9.39 C^{b}$ & $163.17 \pm 4.85 C^{\mathrm{ab}}$ & $178.40 \pm 9.83 C^{a}$ \\
\hline & TBY1 & $125.34 \pm 6.69 \mathrm{C}^{\mathrm{a}}$ & $143.67 \pm 16.02 \mathrm{C}^{\mathrm{a}}$ & $157.24 \pm 15.84 \mathrm{C}^{\mathrm{a}}$ \\
\hline & TBY2 & $145.19 \pm 18.80 \mathrm{Ca}^{\mathrm{a}}$ & $159.31 \pm 12.25 \mathrm{C}^{\mathrm{a}}$ & $175.49 \pm 23.21 \mathrm{C}^{\mathrm{a}}$ \\
\hline \multirow{7}{*}{ 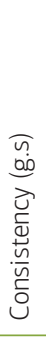 } & CFY & $5412 \pm 413 A^{a}$ & $5865 \pm 407 \mathrm{AB}^{\mathrm{a}}$ & $6159 \pm 363 \mathrm{AB}^{\mathrm{a}}$ \\
\hline & CNY & $5280 \pm 312 \mathrm{~A}^{a}$ & $5589 \pm 247 \mathrm{~B}^{\mathrm{a}}$ & $5807 \pm 396 \mathrm{BC}^{\mathrm{a}}$ \\
\hline & TY1 & $5724 \pm 524 A^{a}$ & $6147 \pm 511 \mathrm{AB}^{\mathrm{a}}$ & $6573 \pm 617 A^{a}$ \\
\hline & TY2 & $6554 \pm 450 A^{a}$ & $6871 \pm 618 A^{a}$ & $7542 \pm 456 \mathrm{~A}^{\mathrm{a}}$ \\
\hline & TY3 & $3365 \pm 214 \mathrm{~B}^{\mathrm{b}}$ & $3993 \pm 131 C^{a b}$ & $4370 \pm 241 B C D^{a}$ \\
\hline & TBY1 & $3149 \pm 174 \mathrm{~B}^{\mathrm{a}}$ & $3155 \pm 239 \mathrm{C}^{\mathrm{a}}$ & $2601 \pm 1149 \mathrm{D}^{\mathrm{a}}$ \\
\hline & TBY2 & $3167 \pm 608 \mathrm{~B}^{\mathrm{a}}$ & $3736 \pm 347 \mathrm{Ca}^{\mathrm{a}}$ & $4042 \pm 318 C D^{a}$ \\
\hline \multirow{7}{*}{ 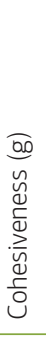 } & CFY & $-171.82 \pm 6.21 \mathrm{~B}^{\mathrm{a}}$ & $-173.06 \pm 13.28 \mathrm{~B}^{\mathrm{a}}$ & $-171.55 \pm 11.68 \mathrm{~B}^{\mathrm{a}}$ \\
\hline & $\mathrm{CNY}$ & $-154.97 \pm 10.73 \mathrm{~B}^{\mathrm{a}}$ & $-161.34 \pm 13.45 \mathrm{~B}^{\mathrm{a}}$ & $-170.78 \pm 11.64 \mathrm{~B}^{\mathrm{a}}$ \\
\hline & TY1 & $-162.20 \pm 14.81 \mathrm{~B}^{\mathrm{a}}$ & $-173.94 \pm 21.87 \mathrm{~B}^{\mathrm{a}}$ & $-163.77 \pm 16.66 \mathrm{~B}^{\mathrm{a}}$ \\
\hline & TY2 & $-180.86 \pm 10.28 \mathrm{~B}^{\mathrm{a}}$ & $-180.95 \pm 17.64 \mathrm{~B}^{\mathrm{a}}$ & $-204.08 \pm 14.33 \mathrm{~B}^{\mathrm{a}}$ \\
\hline & TY3 & $-97.70 \pm 8.11 A^{a}$ & $-105.67 \pm 7.02 \mathrm{~A}^{\mathrm{a}}$ & $-106.93 \pm 12.17 A^{a}$ \\
\hline & TBY1 & $-115.80 \pm 4.15 A^{a}$ & $-113.14 \pm 11.10 \mathrm{~A}^{\mathrm{a}}$ & $-125.28 \pm 9.84 \mathrm{~A}^{\mathrm{a}}$ \\
\hline & TBY2 & $-109.48 \pm 13.00 A^{a}$ & $-113.49 \pm 12.92 \mathrm{~A}^{\mathrm{a}}$ & $-118.09 \pm 9.06 A^{a}$ \\
\hline \multirow{7}{*}{ 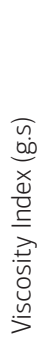 } & CFY & $-394.64 \pm 22.90 B^{a}$ & $-414.22 \pm 29.70 B^{a}$ & $-419.85 \pm 17.23 \mathrm{~B}^{\mathrm{a}}$ \\
\hline & CNY & $-350.26 \pm 19.06 B^{a}$ & $-366.80 \pm 26.18 \mathrm{~B}^{\mathrm{a}}$ & $-389.57 \pm 25.51 \mathrm{~B}^{\mathrm{a}}$ \\
\hline & TY1 & $-355.15 \pm 33.74 \mathrm{~B}^{\mathrm{a}}$ & $-390.46 \pm 45.63 B^{a}$ & $-393.25 \pm 47.10 \mathrm{~B}^{\mathrm{a}}$ \\
\hline & TY2 & $-389.08 \pm 40.17 \mathrm{~B}^{\mathrm{a}}$ & $-432.46 \pm 60.94 \mathrm{~B}^{\mathrm{a}}$ & $-480.76 \pm 40.40 B^{a}$ \\
\hline & TY3 & $-191.49 \pm 27.25 \mathrm{~A}^{\mathrm{a}}$ & $-215.71 \pm 22.77 A^{a}$ & $-213.68 \pm 31.08 A^{a}$ \\
\hline & TBY1 & $-240.60 \pm 9.01 A^{a}$ & $-234.78 \pm 14.44 A^{a}$ & $-261.48 \pm 18.19 A^{a}$ \\
\hline & TBY2 & $-232.14 \pm 23.40 A^{a}$ & $-242.19 \pm 25.69 A^{a}$ & $-256.24 \pm 5.21 A^{a}$ \\
\hline
\end{tabular}

a-b Means in the same raw with different letters were significantly different at $\mathrm{P}<0.05$

A-D Means in the same column with different letters were significantly different at $P<0.05$

interaction leading to creation of casein network by linking the casein micelles via the thin filaments of gum (Aziznia et al., 2009; Wu et al., 2015). On the other hand, yoghurts manufactured using the mixture of TC and BP had the lowest consistency among the samples. Krzeminski et al. (2014) reported that good integration between proteins and polysaccharides reflected by higher viscosity values in reduced-fat yoghurt manufactured with contribution of whey proteins and pectin. Howev$\mathrm{er}$, in the present study, the use of TG-BP mixtures led to a decrease in consistency scores of yoghurts compared with yoghurt manufactured with 0.25 and $0.5 \mathrm{gL}^{-1}$ of TG. These results were in compliance with the firmness values of yoghurt samples and it seems that interactions of casein micelles with $\mathrm{TG}$ and $\mathrm{BP}$ are the main reason for differences in consistency values of yoghurt samples. At simultaneous presence of TG as a polysaccharide agent for trapping water and BP which contains MFGM and high rate of protein, a competition may have occurred between them for interaction with milk caseins. Consequently the effective milk protein/polysaccharide bonds may have been less created than 
TABLE 2. Colour properties of yoghurts manufactured with different concentrations of TG or BP and their combinations ( $n=3$ )

\begin{tabular}{|c|c|c|c|c|}
\hline & Yoghurts & Day 1 & Day 8 & Day 15 \\
\hline \multirow{7}{*}{$\frac{\stackrel{0}{J}}{\stackrel{*}{N}}$} & CFY & $88.82 \pm 0.52 \mathrm{~A}^{\mathrm{a}}$ & $89.06 \pm 0.22 A^{a}$ & $87.96 \pm 0.61 \mathrm{~A}^{\mathrm{a}}$ \\
\hline & CNY & $88.55 \pm 0.13 A^{a}$ & $88.43 \pm 0.24 A^{a}$ & $87.42 \pm 0.53 A^{a}$ \\
\hline & TY1 & $88.31 \pm 0.15 A^{a}$ & $88.07 \pm 0.20 A^{a}$ & $87.39 \pm 0.18 A^{b}$ \\
\hline & TY2 & $87.56 \pm 0.24 \mathrm{~B}^{\mathrm{a}}$ & $87.32 \pm 0.46 \mathrm{~B}^{\mathrm{a}}$ & $86.40 \pm 0.63 \mathrm{~B}^{\mathrm{a}}$ \\
\hline & TY3 & $81.78 \pm 0.35 \mathrm{E}^{\mathrm{a}}$ & $81.19 \pm 0.68 D^{a}$ & $80.27 \pm 0.28 D^{a}$ \\
\hline & TBY1 & $85.00 \pm 0.30 C^{a}$ & $84.78 \pm 0.22 \mathrm{Ca}^{\mathrm{a}}$ & $84.16 \pm 0.22 C^{a}$ \\
\hline & TBY2 & $83.97 \pm 0.32 \mathrm{D}^{\mathrm{a}}$ & $83.78 \pm 0.55 C^{a}$ & $83.15 \pm 0.57 C^{a}$ \\
\hline \multirow{7}{*}{ 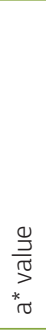 } & CFY & $-2.03 \pm 0.05 A^{a}$ & $-2.12 \pm 0.01 C^{a}$ & $-2.01 \pm 0.06 C^{a}$ \\
\hline & CNY & $-2.55 \pm 0.06 A^{a}$ & $-2.64 \pm 0.08 D^{a}$ & $-2.52 \pm 0.11 \mathrm{D}^{\mathrm{a}}$ \\
\hline & TY1 & $-2.62 \pm 0.06 A^{a}$ & $-2.78 \pm 0.06 D^{a}$ & $-2.70 \pm 0.06 D^{a}$ \\
\hline & TY2 & $-2.84 \pm 0.07 A^{a}$ & $-3.00 \pm 0.04 E^{a}$ & $-2.81 \pm 0.06 E^{a}$ \\
\hline & TY3 & $-3.33 \pm 2.60 A^{a}$ & $-4.18 \pm 0.08 \mathrm{Fa}^{\mathrm{a}}$ & $-3.98 \pm 0.10 \mathrm{Fa}^{\mathrm{a}}$ \\
\hline & TBY1 & $-0.24 \pm 0.04 A^{a}$ & $-0.30 \pm 0.07 A^{a}$ & $-0.36 \pm 0.06 A^{a}$ \\
\hline & TBY2 & $-0.56 \pm 0.03 A^{a}$ & $-0.58 \pm 0.07 \mathrm{~B}^{\mathrm{a}}$ & $-0.61 \pm 0.06 \mathrm{~B}^{\mathrm{a}}$ \\
\hline \multirow{7}{*}{ مـ } & CFY & $8.20 \pm 0.06 C^{a}$ & $8.77 \pm 0.14 C D^{a}$ & $8.58 \pm 0.22 \mathrm{C}^{\mathrm{a}}$ \\
\hline & CNY & $8.03 \pm 0.08 C^{a}$ & $8.48 \pm 0.09 D^{\mathrm{a}}$ & $8.39 \pm 0.30 C^{a}$ \\
\hline & TY1 & $8.09 \pm 0.10 \mathrm{Ca}^{\mathrm{a}}$ & $8.70 \pm 0.11 C D^{a}$ & $8.60 \pm 0.23 C^{b}$ \\
\hline & TY2 & $8.21 \pm 0.11 \mathrm{Ca}^{\mathrm{a}}$ & $8.98 \pm 0.15 C D^{a}$ & $8.83 \pm 0.29 \mathrm{Ca}^{\mathrm{a}}$ \\
\hline & TY3 & $8.35 \pm 0.32 C^{b}$ & $9.09 \pm 0.21 C^{\mathrm{ab}}$ & $8.89 \pm 0.15 C^{b}$ \\
\hline & TBY1 & $11.87 \pm 0.34 \mathrm{~B}^{\mathrm{a}}$ & $12.13 \pm 0.30 \mathrm{~B}^{\mathrm{a}}$ & $12.00 \pm 0.38 \mathrm{~B}^{\mathrm{a}}$ \\
\hline & TBY2 & $12.87 \pm 0.18 A^{a}$ & $13.30 \pm 0.21 A^{a}$ & $13.30 \pm 0.15 A^{a}$ \\
\hline \multirow{7}{*}{$\begin{array}{l}\text { है } \\
\text { 일 } \\
\text { ᄅ̇ }\end{array}$} & CFY & $8.45 \pm 0.06 C^{a}$ & $9.02 \pm 0.13 \mathrm{DE}^{\mathrm{a}}$ & $8.81 \pm 0.22 \mathrm{D}^{\mathrm{a}}$ \\
\hline & CNY & $8.42 \pm 0.08 \mathrm{Ca}^{\mathrm{a}}$ & $8.88 \pm 0.07 \mathrm{E}^{\mathrm{a}}$ & $8.76 \pm 0.31 \mathrm{D}^{\mathrm{a}}$ \\
\hline & TY1 & $8.50 \pm 0.09 \mathrm{Ca}^{\mathrm{a}}$ & $9.13 \pm 0.08 \mathrm{DE}^{\mathrm{a}}$ & $9.02 \pm 0.23 C D^{a}$ \\
\hline & TY2 & $8.69 \pm 0.11 \mathrm{Ca}^{\mathrm{a}}$ & $9.47 \pm 0.12 \mathrm{D}^{\mathrm{a}}$ & $9.27 \pm 0.28 C D^{a}$ \\
\hline & TY3 & $8.99 \pm 0.34 \mathrm{C}^{\mathrm{a}}$ & $10.01 \pm 0.17 C^{a}$ & $9.74 \pm 0.16 \mathrm{C}^{\mathrm{a}}$ \\
\hline & TBY1 & $11.87 \pm 0.34 \mathrm{~B}^{\mathrm{a}}$ & $12.13 \pm 0.27 \mathrm{~B}^{\mathrm{a}}$ & $12.01 \pm 0.36 \mathrm{~B}^{\mathrm{a}}$ \\
\hline & TBY2 & $12.88 \pm 0.19 \mathrm{~A}^{\mathrm{a}}$ & $13.31 \pm 0.21 \mathrm{~A}^{\mathrm{a}}$ & $13.31 \pm 0.15 \mathrm{~A}^{\mathrm{a}}$ \\
\hline \multirow{7}{*}{ 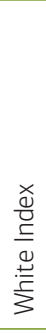 } & CFY & $85.97 \pm 0.39 A^{a}$ & $85.82 \pm 0.24 A^{a}$ & $85.06 \pm 0.37 A^{a}$ \\
\hline & CNY & $85.79 \pm 0.08 A^{a}$ & $85.41 \pm 0.17 \mathrm{~A}^{\mathrm{a}}$ & $84.65 \pm 0.27 A^{b}$ \\
\hline & TY1 & $85.54 \pm 0.11 A^{a}$ & $84.97 \pm 0.17 \mathrm{AB}^{\mathrm{b}}$ & $84.49 \pm 0.04 A^{c}$ \\
\hline & TY2 & $84.83 \pm 0.23 \mathrm{~B}^{\mathrm{a}}$ & $84.18 \pm 0.37 B^{a}$ & $83.54 \pm 0.36 \mathrm{~B}^{\mathrm{a}}$ \\
\hline & TY3 & $79.68 \pm 0.40 D^{a}$ & $78.69 \pm 0.61 \mathrm{D}^{\mathrm{a}}$ & $78.00 \pm 0.18 \mathrm{D}^{\mathrm{a}}$ \\
\hline & TBY1 & $80.87 \pm 0.12 C^{a}$ & $80.54 \pm 0.01 C^{a}$ & $80.12 \pm 0.13 C^{b}$ \\
\hline & TBY2 & $79.44 \pm 0.36 D^{a}$ & $79.02 \pm 0.54 \mathrm{D}^{\mathrm{a}}$ & $78.52 \pm 0.53 \mathrm{D}^{\mathrm{a}}$ \\
\hline \multirow{7}{*}{ 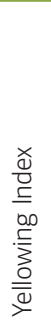 } & CFY & $13.20 \pm 0.07 \mathrm{D}^{\mathrm{a}}$ & $14.06 \pm 0.25 \mathrm{D}^{\mathrm{a}}$ & $13.93 \pm 0.26 \mathrm{D}^{\mathrm{a}}$ \\
\hline & CNY & $12.95 \pm 0.10 D^{\mathrm{a}}$ & $13.70 \pm 0.13 \mathrm{D}^{\mathrm{a}}$ & $13.71 \pm 0.41 \mathrm{D}^{\mathrm{a}}$ \\
\hline & TY1 & $13.08 \pm 0.16 D^{b}$ & $14.11 \pm 0.18 \mathrm{D}^{\mathrm{a}}$ & $14.06 \pm 0.34 \mathrm{D}^{\mathrm{a}}$ \\
\hline & TY2 & $13.40 \pm 0.19 C D^{a}$ & $14.70 \pm 0.25 \mathrm{D}^{\mathrm{a}}$ & $14.60 \pm 0.37 \mathrm{D}^{\mathrm{a}}$ \\
\hline & TY3 & $14.59 \pm 0.58 C^{a}$ & $16.00 \pm 0.38 C^{a}$ & $15.82 \pm 0.21 C^{a}$ \\
\hline & TBY1 & $19.95 \pm 0.51 \mathrm{~B}^{\mathrm{a}}$ & $20.44 \pm 0.40 B^{a}$ & $20.37 \pm 0.58 B^{a}$ \\
\hline & TBY2 & $21.90 \pm 0.40 \mathrm{~A}^{\mathrm{a}}$ & $22.68 \pm 0.50 A^{a}$ & $22.85 \pm 0.41 A^{a}$ \\
\hline
\end{tabular}

${ }^{a-c}$ Means in the same raw with different letters were significantly different at $\mathrm{P}<0.05$

A-E Means in the same column with different letters were significantly different at $P<0.05$ 
the case in which TG used alone and in appropriate concentration for the manufacture of the non-fat yoghurt (Krzeminski et al., 2014; Wu et al., 2015). The consistency value in yoghurt samples increased during 15 days of storage and this increase was not significant except in TY3. Increasing the consistency of yoghurt during storage has also been reported by Karaca et al. (2019) and Oraç and Akın (2019).

Cohesiveness is expressed as the force that can cause deformation of material before it is broken. This value is a measure for strength in internal bonds of a material. In yoghurt, cohesiveness is defined as the highest force applied over the probe while moving out of the yoghurt sample after total immersion and this parameter is related to consumer acceptability of yoghurt (Mousavi et al., 2019; Karaca et al., 2019). Cohesiveness values of yoghurt samples are given in Table 1 with negative values which indicate the direction of the force. Cohesiveness of yoghurt samples increased with increasing the level of TG from 0.25 to $0.50 \mathrm{gL}^{-1}$. However, this increase was statistically insignificant ( $p>0.05$ ). On the other hand, use of $1 \mathrm{gL}^{-1}$ of TG resulted in lowest value of cohesiveness among yoghurt samples $(p<0.05)$. Based on these data, it can be suggested that TG in concentrations of 0.25 to $0.50 \mathrm{gL}^{-1}$ had a higher water absorption capacity in protein matrix of yoghurt and can provide the cohesiveness (Ozturk et al., 2018). It has previously been reported that cohesiveness increased in yoghurts supplemented with partially hydrolysed guar gum and oat-maltodextrin (Domagala et al., 2005; Mudgil et al., 2017). On the other hand, the cohesiveness value in yoghurt manufactured with simultaneous use of TG and BP was significantly $(p<0.05)$ lower than control full-fat and control non-fat yoghurts.

The area under the force versus time curve is expressed as viscosity index. Using various amounts of TG in manufacture of non-fat yoghurt caused different changes in the viscosity index value. While using TG in amounts of 0.25 and $0.50 \mathrm{gL}^{-1}$ caused an improvement in the viscosity of non-fat yoghurts, incorporation of $1 \mathrm{gL}^{-1}$ of tara gum resulted in lower viscosity. High concentrations of polysaccharide gums may lead to decrease in $\mathrm{pH}$ value and extensive rearrangement of protein particles. This situation may cause to form a coarser structure with large pores which leads to final product with lower viscosity (Aziznia et al., 2008; Crispin-Isidro et al., 2015). On the other hand, supplementation of non-fat yoghurt with TG and BP did not improve the viscosity index of non-fat yoghurt.

\section{Colour parameters of yoghurts}

Light dispersion of casein micelles and fat globules are responsible for presence of white colour in dairy products (Mousavi et al., 2019). In this study, while TG alone or in combination with BP had significant $(p<0.05)$ effect on colour parameters of yoghurt samples, no significant changes were observed in colour intensity during storage time ( $p>0.05$ ) (Table 2). Increasing the amount of TG from 0.25 to $1 \mathrm{gL}^{-1}$ led to a significant decrease $(p<0.05)$ in $L^{*}$ value of yoghurts compared with control full-fat and control non-fat yoghurt. The gum used in yoghurt formulation can bond the free water in the matrix of product and influence the $L^{*}$ value of yoghurt, as in the present study, using higher concentrations of TG resulted in less $L^{*}$ value and darker appearance in yoghurt samples (Singh et al., 2012; Mousavi et al., 2019). Furthermore, addition of BP with TG caused a decrease in $L^{*}$ value of yoghurts, compared with yoghurts manufactured only with TG or control ones. The highest $L^{*}$ value was determined in a control full-fat yoghurt. Similar results were reported by Mousavi et al. (2019) for yoghurts with the addition of flaxseed, $\mathrm{K}$ as well as by Karaca et al. (2019) for yoghurts fortified with persimmon and apple powders. Furthermore, possible interactions between TG or BP and milk proteins can form greater particles in yoghurt and influence the diffraction pattern (Keshtkaran et al., 2013).

The highest and the lowest $a^{*}$ values (redness) during the storage were recorded in TBY1 and TY3, respectively. Higher concentrations of polysaccharides used for manufacturing of yoghurt may lead to formation of higher dry matter, reduction of diffraction pattern and decrease $a^{*}$ values during storage. In a similar study, Singh et al. (2012), reported that $a^{*}$ values in yoghurts supplemented with purified oat $\beta$-glucan decreased with increasing the $\beta$-glucan used in formulation. Supplementation of yoghurt with addition of TG and BP also caused to increase in $\mathrm{a}^{*}$ values of yoghurt compared to control full-fat and non-fat yoghurts. Addition of protein source to milk could be increased the protein-protein interactions. During manufacturing of yoghurt, application 
of heat treatment can influence the heat-sensitive compounds i.e. proteins and led to Maillard reaction. This phenomenon can be an effective factor in degradation of proteins and change in $a^{*}$ value in yoghurt supplemented with TG and BP (Delikanli and Ozcan, 2017; Gélébart et al., 2019).

Using various combinations of TG and BP led to an increase in $b^{*}$ values in yoghurts and this increase was significant $(p<0.05)$ in yoghurts manufactured with combinations of TG and BP compared with control yoghurts. The highest $b^{*}$ value was determined in TBY2 compared to other yoghurt samples. Interactions of polysaccharide and proteins originating from TG or BP with milk proteins may lead to trapping more free water, increasing the dry matter and more yellowness in yoghurt (Singh et al., 2012; Mousavi et al., 2019).

The chroma $\left(C^{*}\right)$ measures the degree of colourfulness of the yoghurts and the addition of TG and $\mathrm{BP}$ increased the $\mathrm{C}^{*}$ values of the yoghurt samples $(p<0.05)$. This situation indicates a higher colour intensity that may affect the consumers' preferences (Pathare et al., 2013). However, no significant difference was found in $C^{*}$ values for all samples during the storage time ( $p>0.05)$. Akeem et al. (2018) have reported the $C^{*}$ values of the full-cream cow-coconut milk yoghurts increased with the increase in the level of coconut milk substitution.

White index (WI) showed a significant fall for the TG and combinations of TG with BP yoghurts compared with control yoghurt samples and the decrease was significant $(p<0.05)$. Marand et al. (2020) reported similar findings that the $L^{*}$ and WI values of yoghurts decreased by increasing the flaxseed powder content. On the first day of storage, control yoghurts had the highest WI, followed by TY1, TY2, TBY1, TY3 and TBY2 samples, respectively. On the $15^{\text {th }}$ day of storage a slight decrease in WI was observed for all yoghurts.

Yellowing Index (YI) values exhibited an increasing trend in yoghurt supplemented with TG and BP $(p<0.05)$. The value of the $Y I$ was the highest for TBY2 and the lowest for control non-fat yoghurts. The $\mathrm{YI}$ value was in accordance with the findings by Bierzunska et al. (2019) for yoghurt with whey protein concentrate and Marand et al. (2020) for yoghurt enriched with flaxseed powder. It was observed that this value in yoghurt samples were increased during storage but the increase was not significant except in TY3. The YI of yoghurt with whey protein concentrate increased with storage time was also reported by Bierzunska et al. (2019).

\section{Sensory attributes of yoghurts}

Sensory assessment is related to product characteristics which are the main parameters for customer acceptability (Mousavi et al., 2019). The results of sensory characteristic of yoghurts are given in Figure 2. The sensory characteristics of yoghurt samples are significantly affected by the presence of different combinations of TG and BP $(p<0.05)$. CFY had a significantly higher sensory score among yoghurt samples during storage $(p<0.05)$. In yoghurts supplemented with TG, increasing the concentration of TG from 0.25 to $1 \mathrm{gL}^{-1}$ caused a significant decrease in appearance, odour and taste $(p<0.05)$. Non-fat yoghurts manufactured using 0.25 and $0.5 \mathrm{gL}^{-1}$ of TC had close values of consistency (as perceived by spoon or mouth) to control yoghurts probably due to interactions between TG and milk proteins and due to formation of a strengthened casein network by linking casein micelles via the thin filaments of gum. On the other hand, a significant decrease $(p<0.05)$ was determined in consistency (as perceived by spoon or mouth) of non-fat yoghurt manufactured using high concentration of TG $\left(1 \mathrm{gL}^{-1}\right)$ compared to control yoghurts. The use of high concentrations of TG in yoghurt manufacture may cause an increase in the distance between casein micelles. This phenomenon participates in creation of loops and tails in network of yoghurt and weakening of gel (Everett and McLeod, 2005; Wu et al., 2015). Use of TG in combination with BP caused a relatively higher consistency (as perceived by spoon or mouth) values in TBY1 and TBY2. Sodini et al. (2006) demonstrated that high contents of casein and milk fat globule membrane (MFGM) components in buttermilk powder can contribute to the development of yoghurt structure.

Different TG concentrations influenced significantly $(p<0.05)$ the odour and taste scores of yoghurts. Yoghurt samples manufactured with 0.25 and $0.5 \mathrm{gL}^{-1}$ of TG exhibited high odour and taste scores by the sensory panel whereas increasing the TC concentration to $1 \mathrm{gL}^{-1}$ had a negative effect on odour and taste scores of yoghurts. Odour and taste scores pinpointed that TY3 was perceived as having less desirable 

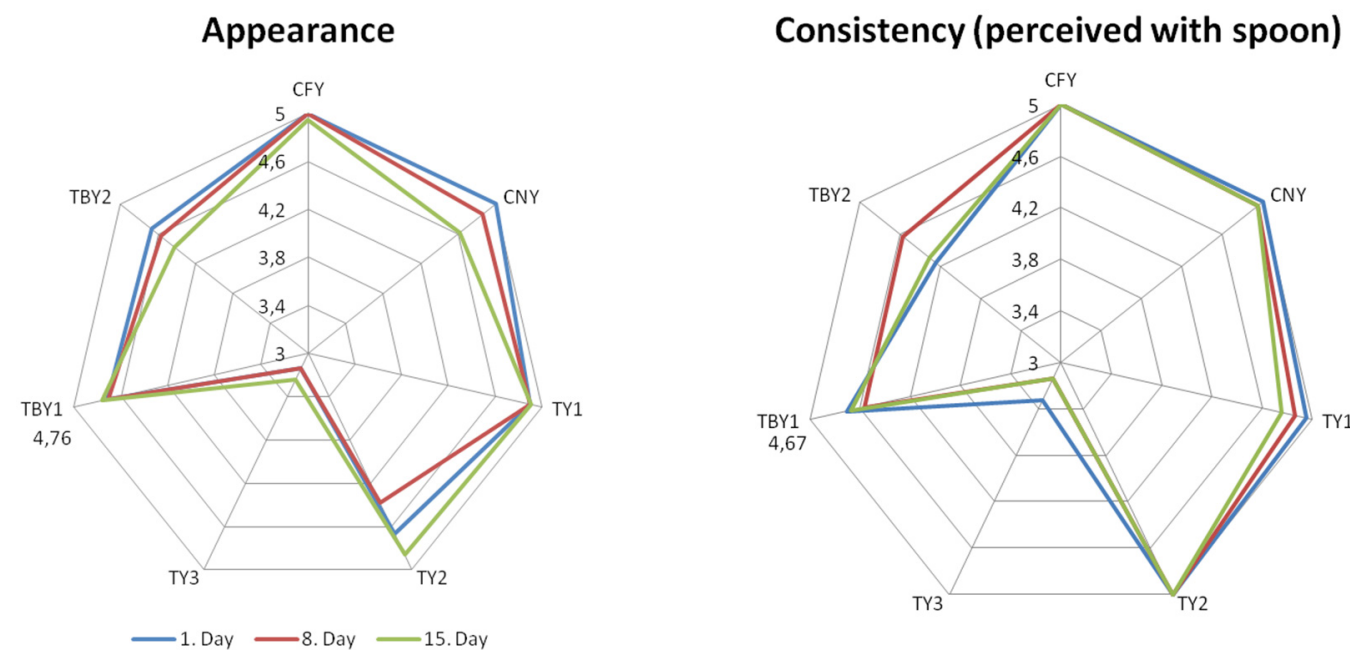

\section{Consistency (perceived with mouth)}
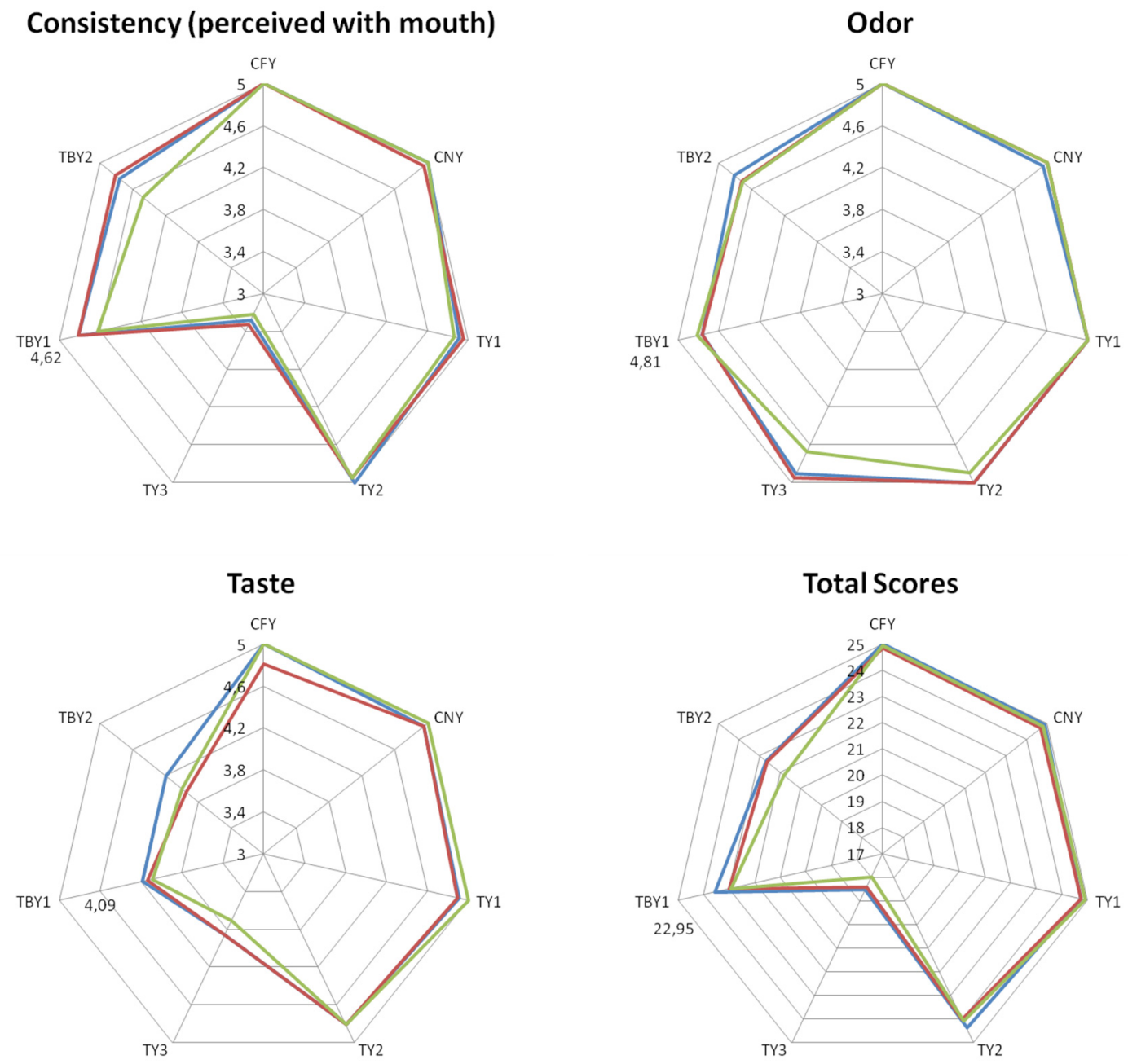

FIGURE 2. Sensory properties of yoghurts manufactured with different concentrations of TG or BP and their combinations 
odour and taste than CFY and CNY. Additionally, yoghurt samples manufactured using TG-BP mixtures received significantly lower odour and taste scores $(p<0.05)$ compared to control yoghurts.

As presented in Figure 2, storage period did not significantly influence the total sensory scores of yoghurts whereas this parameter was significantly $(p<0.05)$ decreased by increasing TG concentration in yoghurts manufactured with various rates of this gum. Addition of $1 \mathrm{gL}^{-1}$ of TG caused a significant $(p<0.05)$ decrease in total sensory scores of TY3 compared to CFY and CNY. This situation was also seen in yoghurt manufactured using the mixture of $\mathrm{TC}$ and $\mathrm{BP}$, while the total sensory scores of TBY1 and TBY2 were significantly $(p<0.05)$ lower than that of control yoghurts. This results indicated that the use of TG and $\mathrm{BP}$ at the same time as fat replacer for the manufacture of nonfat yoghurt did not achieve the panelists' satisfaction in terms of sensory properties.

\section{Conclusions}

Texture, colour and sensory characteristics of yoghurts were affected significantly $(p<0.05)$ by different concentrations of TG or various combinations of TG and BP used during manufacturing of samples. Addition of 0.25 and $0.50 \mathrm{gL}^{-1}$ of TG improved the firmness, consistency and increase in cohesiveness and viscosity index values of non-fat yoghurt. On the other hand, significant decrease $(p<0.05)$ was determined in firmness, consistency and viscosity index of yoghurt manufactured using mixture of TC and BP. Significant changes $(p<0.05)$ were determined in yoghurts manufactured with TG or different combinations of TG and BP. Furthermore, yoghurts manufactured with addition of TG or different combinations of TG and BP had generally lower scores for appearance, consistency, odour and taste than control full-fat and control non-fat yoghurts. It can be stated that using combinations of hydrocolloids such as TG and a protein-based by-product such as BP in certain concentrations can help to improve texture properties of non-fat yoghurt. However, further research is necessary to develop formulations in order to improve the colour and sensory characteristics of the final product.

\section{Acknowledgements}

This work was supported by the Cukurova University, Unit of Scientific and Research Projects, Turkey (grant number POZMER2012BAP1).

The authors are grateful to Ela Gursoy (Lecturer in School of Foreign Language, Cukurova University) for checked the English version of the manuscript.

\section{Tekstura, boja i senzorska svojstva nemasnog jogurta s dodatkom tara gume ili kombinacije tara gume i mlaćenice u prahu}

\section{Sažetak}

Tekstura, boja i senzorska svojstva nemasnog jogurta proizvedenog uz dodatak različitih koncentracija tara gume $\left(0,25,0,50\right.$ i 1,0 $\left.\mathrm{gL}^{-1}\right)$ kao različitih omjera tara gume (TG) i mlaćenice u prahu (BP) $(0,25+10$, 0,50+10 and 1,0+10 $\mathrm{gL}^{-1}$ ) ispitivani su tijekom perioda skladištenja. Dodatak tara gume u koncentracijama 0,25 i 0,50 gL-1 uzrokovao je porast čvrstoće, konzistencije, kohezivnosti i indeksa viskoznosti u proizvedenim uzorcima jogurta, dok je dodatak tara gume ili tara gume u kombinaciji s mlaćenicom u prahu u koncentraciji od $1 \mathrm{gL}^{-1}$ uzrokovao smanjenje prethodno navedenih parametara. Povećanje koncentracije dodane tara gume tijekom perioda skladištenja uzrokovalo je značajan pad $L^{*}$ i a* vrijednosti, te značajan porast b* vrijednosti jogurta. Senzorska svojstva nemasnih jogurta proizvedenih s dodatkom 0,25 i 0,50 $\mathrm{gL}^{-1}$ tara gume nisu se značajno razlikovala od kontrolnih uzoraka. Suprotno tomu, dodatak tara gume ili kombinacije mlaćenice u prahu i tara gume u koncentracijama od $1 \mathrm{gL}^{-1}$ uzrokovao je značajan pad senzorskih ocjena uzoraka nemasnog jogurta.

Ključne riječi: mlaćenica u prahu, nemasni jogurt, senzorska svojstva, tara guma, tekstura 
1. Akeem, S.A., Yerumoh, O., Leigh, O., Bamgbala, K., Okeke, G., Sokunbi, F., Olayıwola, I. (2018): Physicochemical properties, colour characteristics, and sensory evaluation of full-cream cow-coconut milk yoghurts. Croatian Journal of Food Science and Technology 10, 226-233. https://doi.org/10.17508/CJFST.2018.10.2.13

2. Ali, A.H. (2019): Current knowledge of buttermilk: Composition, applications in the food industry, nutritional and beneficial health characteristics. International Journal of Dairy Technology 72, 169-182.

https://doi.org/10.1111/1471-0307.12572

3. Anonymous (1989): Yoghurt. TS 1330 Turkish Standards Institution, 10 pages, Ankara, Turkey.

4. $\quad$ Antoniou, J., Liu, F., Majeed, H., Qazi, H.J., Zhong, F. (2014): Physicochemical and thermomechanical characterization of tara gum edible films: effect of polyols as plasticizers. Carbohydrate Polymers 111, 359-365. https://doi.org/10.1016/j.carbpol.2014.04.005

5. Aziznia, S., Khosrowshahi, A., Madadlou, A., Rahimi, J. (2008): Whey protein concentrate and Gum Tragacanth as fat replacers in non-fat yoghurt: chemical, physical and microstructural properties. Journal of Dairy Science 91, 2545-2552.

https://doi.org/10.3168/jds.2007-0875

6. Aziznia, S., Khosrowshahi, A., Madadlou, A., Rahimi, J., Abbasi, H. (2009): Texture of nonfat yoghurt as influenced by whey protein concentrate and Gum Tragacanth as fat replacers. International Journal of Dairy Technology 62, 405-410. https://doi.org/10.1111/j.1471-0307.2009.00507.x

7. Balthazar, C.F., Gaze, L.V., Silva, H.L.A. (2015): Sensory evaluation of ovine milk yoghurt with inulin addition. International Journal of Dairy Technology 68, 281-290. https://doi.org/10.1111/1471-0307.12189

8. Bierzunska, P., Cais-Sokolinska, D., Yiğit, A. (2019): Storage stability of texture and sensory properties of yoghurt with the addition of polymerized whey proteins. Foods 8, 548. https://doi.org/10.3390/foods8110548

9. Brennan, C.S., Tudorica, C.M. (2008): Carbohydrate-based fat replacers in the modification of the rheological, textural and sensory quality of yoghurt: comparative study of the utilisation of barley beta-glucan, guar gum and inulin. International Journal of Food Science and Technology 43, 824-833. https://doi.org/10.1111/j.1365-2621.2007.01522.x

10. Crispin-Isidro, G., Lobato-Calleros, C., Espinosa-Andrews, H., Alvarez-Ramirez, J., Vernon-Carter, E. J. (2015): Effect of inulin and agave fructans addition on the rheological, microstructural and sensory properties of reduced-fat stirred yoghurt. LWT-Food Science and Technology 62, 438-444. https://doi.org/10.1016/j.lwt.2014.06.042

11. Delikanli, B., Ozcan, T. (2017): Improving the textural properties of yogurt fortified with milk proteins. Journal of Food Processing and Preservation 41: e13101. https://doi.org/10.1111/jfpp.13101
12. Dewettinck, K., Rombaut, R., Thienpont, N., Le, T.T., Messens, K., Van-Camp, J. (2008): Nutritional and technological aspects of milk fat globule membrane material. International Dairy Journal 18, 436-457. https://doi.org/10.1016/j.idairyj.2007.10.014

13. Dinkci, N. (2012): The influence of transglutaminase treatment on functional properties of strained yoghurt. Journal of Animal and Veterinary Advance 11, 2238-2246. https://doi.org/10.3923/javaa.2012.2238.2246

14. Domagala, J., Sady, M., Grega, T., Bonczar, G. (2005): The influence of storage time on rheological properties and texture of yoghurts with the addition of oat-maltodextrin as the fat substitute. International Journal of Food Properties 8, 395-404. https://doi.org/10.1081/JFP-200059497

15. Everett, D.W., McLeod, R.E. (2005): Interactions of polysaccharide stabilisers with casein aggregates in stirred skim-milk yoghurt. International Dairy Journal 15, 1175-1183. https://doi.org/10.1016/j.idairyj.2004.12.004

16. Gélébart, P., Riaublanc, A., Famelart, M.H., Jonchère, C., Beaumal, V., Anton, M., Garnier, C. (2019): Protein aggregates modulate the texture of emulsified and acidified acid milk gels. Food Hydrocolloids 93, 176-188. https://doi.org/10.1016/j.foodhyd.2019.02.007

17. Guo, X., Xie, Z.H., Wang, G., Zou, Q., Tang, R. (2018): Effect on nutritional, sensory, textural and microbiological properties of low-fat yoghurt supplemented with Jerusalem artichoke powder. International Journal of Dairy Technology 71, 167-174. https://doi.org/10.1111/1471-0307.12404

18. Guven, M., Yasar, K., Karaca, O.B., Hayaloglu, A.A. (2005): The effect of inulin as a fat replacer on the quality of settype low-fat yoghurt manufacture. International Journal of Dairy Technology 58, 180-184. https://doi.org/10.1111/j.1471-0307.2005.00210.x

19. Güler, Z., Park, Y.W. (2011): Characteristics of physicochemical properties, volatile compounds and free fatty acid profiles of commercial set-type Turkish yoghurts. Open Journal of Animal Sciences 1, 1-9. https://doi.org/10.4236/ojas.2011.11001

20. Karaca, O.B., Saydam, I.B., Güven, M. (2019): Physical, chemical, and sensory attributes of low-fat, full-fat, and fat-free probiotic set yogurts fortified with fiber-rich persimmon and apple powders. Journal of Food Processing and Preservation 43, e13926. https://doi.org/10.1111/jfpp.13926

21. Keshtkaran, M., Mohammadifar, M.A., Asadi, G.H., Nejad, R.A., Balaghi, S. (2013): Effect of gum tragacanth on rheological and physical properties of a flavored milk drink made with date syrup. Journal of Dairy Science 96, 4794-4803. https://doi.org/10.3168/jds.2012-5942

22. Krzeminski, A., Prell, K.A., Busch-Stockfisch, M., Weiss, J., Hinrichs, J. (2014): Whey protein-pectin complexes as new texturising elements in fat-reduced yoghurt systems. International Dairy Journal 36, 118-127. https://doi.org/10.1016/j.idairyj.2014.01.018 
23. Ladjevardi, Z.S., Gharibzahedi, S.M.T., Mousavi, M. (2015): Development of a stable low-fat yogurt gel using functionality of psyllium (Plantago ovata Forsk) husk gum. Carbohydrate polymers 125, 272-280. https://doi.org/10.1016/j.carbpol.2015.02.051

24. Ma, Q., Hu, D., Wang, H., Wang, L. (2016): Tara gum edible film incorporated with oleic acid. Food Hydrocolloids 56, 127-133. https://doi.org/10.1016/j.foodhyd.2015.11.033

25. Marand, M.A., Amjadi, S., Marand, M.A., Roufegarinejad, L., Jafari, S.M. (2020): Fortification of yogurt with flaxseed powder and evaluation of its fatty acid profile, physicochemical, antioxidant, and sensory properties. Powder Technology 359, 76-84. https://doi.org/10.1016/j.powtec.2019.09.082

26. Mousavi, M., Heshmati, A., Daraei Garmakhany, A., Vahidinia, A., Taheri, M. (2019): Texture and sensory characterization of functional yogurt supplemented with flaxseed during cold storage. Food science \& Nutrition 7 , 907-917. https://doi.org/10.1002/fsn3.805

27. Mudgil, D., Barak, S., Khatkar, B.S. (2017): Texture profile analysis of yogurt as influenced by partially hydrolyzed guar gum and process variables. Journal of Food Science and Technology 54, 3810-3817. https://doi.org/10.1007/s13197-017-2779-1

28. Oraç, A., Akın, N. (2019): How do different cooling temperatures affect the characteristics of set-type yoghurt gel?. International Dairy Journal 97, 49-56. https://doi.org/10.1016/j.idairyj.2019.06.003

29. Oztürk, H.I.,, Aydın, S., Sözeri, D., Demirci, T., Sert, D., Akın, N. (2018): Fortification of set-type yoghurts with Elaeagnus angustifolia L. flours: Effects on physicochemical, textural, and microstructural characteristics. LWT-Food Science and Technology 90, 620-626. https://doi.org/10.1016/j.lwt.2018.01.012

30. Pathare, P.B., Opara, U.L., Al-Said, F.A. (2013): Colour measurement and analysis in fresh and processed foods: A Review. Food Bioprocess Technology 6, 36-60. https://doi.org/10.1007/s11947-012-0867-9

31. Pereira, R., Matia-Merino, L., Jones, V., Singh, H. (2006): Influence of fat on the perceived texture of set acid milk gels: A sensory perspective. Food Hydrocolloids 20, 305-313.

https://doi.org/10.1016/j.foodhyd.2005.01.009
32. Romeih, E.A., Abdel-hamid, M., Awad, A.A. (2014): The addition of buttermilk powder and transglutaminase improves textural and organoleptic properties of fat-free buffalo yoghurt. Dairy Science and Technology 94, 297309. https://doi.org/10.1007/s13594-014-0163-8

33. Sah, B.N.P., Vasiljevic, T., McKechnie, S., Donkor, O.N. (2016): Antioxidant peptides isolated from synbiotic yoghurt exhibit antiproliferative activities against HT-29 colon cancer cells. International Dairy Journal 63, 99-106. https://doi.org/10.1016/j.idairyj.2016.08.003

34. Sandoval-Castilla, O., Lobato-Calleros, C., AguirreMandujano, E., Vernon-Carter, F.J. (2004): Microstructure and texture of yoghurt as influenced by fat replacers. International Dairy Journal 14, 151-159. https://doi.org/10.1016/S0958-6946(03)00166-3

35. Singh, M., Kim, S., Liu, S.X. (2012): Effect of purified oat $\beta$-glucan on fermentation of set-style yogurt mix. Journal of Food Science 77, 195-201. https://doi.org/10.1111/j.1750-3841.2012.02828.x

36. Sodini, I., Morin, P., Olabi, A., Jiménez-Flores, R. (2006): Compositional and functional properties of buttermilk: a comparison between sweet, sour, and whey buttermilk. Journal of Dairy Science 89, 525-536. https://doi.org/10.3168/jds.S0022-0302(06)72115-4

37. Ünal, B., Metin, S., Develi Işıkı, N. (2003): Use of response surface methodology to describe the combined effect of storage time, locust bean gum and dry matter of milk on the physical properties of low-fat set yoghurt. International Dairy Journal 13, 909-916. https://doi.org/10.1016/S0958-6946(03)00118-3

38. Wu, Y., Ding, W., Jia, L., He, Q. (2015): The rheological properties of tara gum (Caesalpinia spinisa). Food Chemistry 168, 366-371. https://doi.org/10.1016/j.foodchem.2014.07.083

39. Yıldız, N., Bakırcı, I. (2019): Investigation the use of whey powder and buttermilk powder instead of skim milk powder in yogurt production. Journal of Food Science and Technology 56, 4429-4436. https://doi.org/10.1007/s13197-019-03953-w

40. Zhao, L., Feng, R., Ren, F., Mao, X. (2018): Addition of buttermilk improves the flavor and volatile compound profiles of low-fat yogurt. LWT-Food Science and Technology 98, 9-17. https://doi.org/10.1016/j.lwt.2018.08.029 